\title{
FORMATION OF THE MODERN CONCEPT OF EUROPE IN THE CONTEXT OF SOCIAL NEO-INSTITUTIONALISM
}

\author{
Andrii Falkovskyi ${ }^{1}$, Olga Dzhezhik ${ }^{2}$
}

\begin{abstract}
In the scientific discourse of the XXI century, the concept of modern Europe is being reformed under the influence of reforming the activities of the European Union. Scientific publications and research are conducted based on a study of the policies of the European Union countries, EU institutions and structural elements, and the problems that arise in the process of activity and development. The concept of modern Europe is a general term that embraces European values, the European standard of living, European policy, and European priorities, giving the concept of European studies a stable association with the European Union. In this context, the main causes and consequences for the scientific discourse, political practice, and future development of European countries must be considered. Neoinstitutionalists have attempted to analyse institutions based on atomistic methodology. Institutional transformations, processes of intra-European integration and enlargement of the EU, discussions on membership and exit from the EU raise issues of identity and development of governance in Europe. Europeanisation can be seen as a discourse, governance, and institutionalisation. The first interpretation emphasizes that modern Europe is a discourse, not only ideological but also administrative. In this sense, Europeanisation can be a means of expression of institutional globalization through domestic policy. In the article, the hypothesis is put forward and proved that the interpretation of the concept of modern Europe directly correlates with the future development of the European Union and its members. The dissemination of exclusive practices will help to spread the ideas of radical "Eurosceptics", which could lead to the collapse of the European Union. The inclusive aspect of the concept of Europe is represented by the ideas of "Europeists" who, based on the common history, culture, mentality of the peoples of Europe, substantiate the positive influence on the state development of integration, non-state cooperation, and extrapolation of EU norms and principles into the new territories of Europe. There are three main reasons for shaping the concept of Europe as the boundaries of EU policy: The consolidation of political positions of the European Union and its growing role as an actor in world politics; Essence of the EU enlargement concepts; Features of development within the European community. The modern concept of Europe is considered in the context of a modern multi-level governance model. Therefore, Europeanisation is the interaction of different layers of interests, including structures of regional, multi-level governance, legitimacy of domestic and foreign policy. The impact of the multi-level governance system on the functioning of public administration systems in the Member States and neighbouring countries is considered. Four approaches are identified based on the analysis of relationships between different levels of governance. The necessity of formulating new theoretical paradigms defining the relations between the Member States and the technocratic institutions of the EU, as well as between the Europeanised system of national agencies and the ministries overseeing their activities, has been proved.
\end{abstract}

Key words: neoinstitutionalism, decentralisation, multi-level governance, Europeanisation, social institution, social system.

JEL Classification: D72, F11, F20, H77

\section{Introduction}

In the scientific discourse of the XXI century, the concept of modern Europe is being reformed under the influence of reforming the activities of the
European Union. Scientific publications and research are conducted based on a study of the policies of the European Union countries, EU institutions and structural elements, and the problems that arise in

\footnotetext{
Corresponding author:

${ }^{1}$ Odessa Regional Institute for Public Administration of the

National Academy for Public Administration under the President of Ukraine, Ukraine.

E-mail: andrii.falkovskiu@gmail.com

${ }^{2}$ Odessa National Polytechnic University, Ukraine.

E-mail: dzhezhik_olga@ukr.net
} 
the process of activity and development. The concept of modern Europe is a general term that embraces European values, the European standard of living, European policy, and European priorities, giving the concept of European studies a stable association with the European Union. In this context, the main causes and consequences for the scientific discourse, political practice, and future development of European countries must be considered.

Political associations, unions, and alliances have been formed in Europe for a long time, with the aim of promoting peace and prosperity in the European countries. After the signing of the Schuman Declaration, a new political project was launched, based on the ideological gains of socio-political thought and leading socio-political concepts. The present-day European Union (EU) is the result of a series of political, economic, and cultural associations. Do not having all the attributes of the state, covering most (but not all) European countries, the EU not only became a major actor in world politics but also assumed the role of representative of the interests of entire Europe (Altvater, Mahnkopf, 2007).

The purpose of the article is to identify the possibilities of using neoinstitutionalism tools to predict the impact of the EU's multi-level governance system on the Member States and neighbouring countries. This understanding of Europe implies the need to determine the relationship between the concept of Europe and the future of the EU in world politics, given the ideological foundations of the policy tools, the use of which is postulated and which are actually applied in specific political situations.

\section{The methodology of research}

\subsection{Analysis of modern theories of institutionalism}

In the process of institutional theory development, both internal and external factors play an important role in the scientific knowledge itself. The definition of these factors is caused by the need to explain the features of the methodology of neoinstitutionalism and to clarify its structure. Neoinstitutionalists have attempted to analyse institutions based on atomistic methodology. The internal prerequisites of neoinstitutionalism are: justification of the possibility of introducing non-economic constraints (institutions) into the economic analysis; consistent implementation of the principle of methodological atomism in the analysis of institutions; the enrichment of theoretical tools of institutionalism by game theory; greater effectiveness of neoinstitutionalism in the implementation of the predictive function. Neoinstitutional theory of rational choice, the theory of transaction costs, the economic theory of property rights by G. Simon (1992) correspond to it as theoretical tools. Atomistic methodology, as the basis for building institutionalism, defines the use of abstract modelling as a method for constructing theories, which makes it possible to create models of sufficiently high predictable power (Martynyuk, 2019). At the same time, abstract models replace a real object with an ideal object, thus reducing the value of the empirical base. This methodology is effective enough for conducting general theoretical and applied research of socio-economic systems with a stable market economy, individualistic behavioural attitudes of the population, developed and highly specified system of property rights. The new institutional economy continues the atomistic (individualistic) tradition, corrects the "protective belt" of the research program of neoclassical and neoinstitutional theory, supplements it with the concept of bounded rationality (Comp. S. Ross, 1973). It proposes a more extensive, coherent, and instrumental methodology, which results in its increasing popularity in foreign and domestic science, and claims to be the main focus of modern economic theory.

The concept of "institution" is basic to the theory of institutionalism and denotes a certain custom, the order adopted in society, and their consolidation in the form of law or organization. Ideologists of institutionalism referred to institutions as social and political, so economic phenomena: state, family, private property, corporations, currency system, and so on. Herewith, the concept of "institution" had a corresponding ideological meaning: it meant the desire to expand the subject of economic science, to include non-economic phenomena in the analysis (Lazor, 2010).

Institutionalization is also considered as an important part of the process of modernizing social systems and social relations. The term "institutionalization" has also been used in the political sphere and reflects the phenomena associated with the creation and organization of government agencies or individual bodies responsible for policy making and implementation.

The most commonly used meaning of the term "social institutions" is associated with the characteristic of ordering, formalizing, and standardizing public relations and relationships. Also, the very process of ordering, formalizing, and standardizing social relations and relationships was called "institutionalization", which explains: the process of forming stable patterns of social interaction based on formalized rules, laws, customs, and rituals; legal and organizational consolidation of behaviour patterns and relations formed in society; establishment of the institution (Petroe, 2012).

The definition of "social institutions", which integrates with contemporary social, political, and economic theories, means:

1) historically conditioned forms of organization and regulation of social life that ensure the fulfilment of functions that are vital for society, include a set of norms, roles, prescriptions, behaviour patterns, special institutions, control system; 
2) orderly and to a certain extent well-established social entities, which include social organizations, maintain officially and conventionally adopted rules governing social behaviour in a particular sphere of public life based on the forced or voluntary consent of most members of society to the availability of these rules and organizations;

3) a stable set of formal and informal norms, principles, guidelines governing various spheres of human activity - economic, political, spiritual and, in fact, the social sphere (Petroe, 2012).

Europeanisation can be seen as discourse, governance, and institutionalisation. The first interpretation emphasizes that modern Europe is a discourse, not only ideological but also administrative. In this sense, Europeanisation can be a means of expression of institutional globalization through domestic policy.

The modern concept of Europe is considered in the context of a modern multi-level governance model. Therefore, Europeanisation is the interaction of different layers of interests, including structures of regional, multi-level governance, legitimacy of domestic and foreign policy.

Institutionalisation itself is understood as the emergence of characteristic structures of governance. Institutionalisation is based on the assertion that the most important factor of domestic change is the divergence, inconsistency of the EU and Member States' political institutions. These three theoretical approaches to Europeanisation are certainly not mutually exclusive but rather complementary (Bretherton, Vogler, 2006).

\section{Development of European neoinstitutionalism}

The EU acts as an open project based on changing the foundations of the neighbourhood policy. The concept of Europe emerges as a project to legitimize the foreign and domestic policy of the European Union, as it reflects some of the characteristics of all European countries. There are three main reasons for shaping the concept of Europe as the boundaries of EU policy:

1. The consolidation of the political positions of the European Union and its growing role as an actor in world politics.

2. The essence of the EU enlargement concepts.

3. Features of scientific discourse within the European community.

Considering each of these reasons in more detail, it can be argued that the first one emerges as political in substance since the European Union's foreign and domestic policies are aimed at strengthening the EU's role both in Europe and worldwide. There are no alternative political actors and integration entities in Europe equal to or more powerful than the EU. Using an instrument such as the European Neighbourhood Policy (ENP) and its main components, the European Union extends its influence to neighbouring countries. The EU seeks to influence and control the socio-political, economic, cultural processes in Europe (Davis, 2006).

Second, the essence of the concepts of European Union development and integration is characterized by the application of Joseph Nye's concept of "force" to the European Union, and concepts derived from it, such as the "normative power of Europe", "ethical power of Europe" and others. Thus, Europe can be studied as one that falls within the concept of the modern type of empires.

The third group of reasons is characterized by the fact that basic scientific research is initiated and carried out in the most economically and politically developed countries in Europe, which have formed the "core" of not only the EU but Europe as a whole. After the founding of the European Union, the active creation of European studies began, with the aim of substantiating EU policy towards the Member States, neighbouring countries, and other global actors, and the possible future development, conducted in the context of the formation and possible enlargement of the European Union (Munchler, 2007).

The following three basic theoretical approaches to the formation of the modern concept of Europe can be distinguished (Telo, 2006). State-centric paradigm the state in Europe will always be the main democratic representative of political interests, and the dominance of one or a group of states in inter-state associations will ensure the welfare of all members of the cooperation.

The "neo-medieval" theoretical school points to the "retreat" of the state, caused by the growing role of TNCs and the deterritorialization of power, the emergence of supranational technocratic power and non-territorial communities. This leads to the disappearance of a single centre in the global system and the emergence of different levels of governance that are intertwined.

Neoinstitutionalism allows analysing the multilevel interaction in the domestic and foreign political arenas of Europe of different institutions that correlate the interests of states with the political will of other actors. All three of these views on the place of the state in contemporary Europe have manifestations in political life and characterize the main tendencies of changing the role of the state and regions.

Understanding Europe through identity makes it possible to speak of it as "an inclusive or exclusive concept, which for some served as evidence that they are absolutely guaranteed to belong to Europe while others were thus pushed beyond the European borders" (Kurth, 2003).

Inclusive concept of Europe (from Eng. inclusion) is based on common human values that shape the identity of the community, in particular, respect for human and civil rights. It is the inclusive notion of Europe and the European Union that "reflects a long, probably dominant, discourse that is actively supported within 
the Union" (Bretherton, Vogler, 2006). Inclusive European identity implies communication and interaction with other political-territorial and cultural entities. This can set the conditions for accepting/ rejecting other communities in the circle of Europeans. Those who openly demonstrate a commitment to proclaimed common European values define their commitment to the foundations of European social cohesion and become a part of Europe.

Instead, exclusive identity (from Eng. exclusion) reflects Europe's interaction with the external environment. It is the understanding of Europe as a "fortress" that is formed based on a common market and tight control over external migration. Such a concept - a way of identifying a community in a negative way, that is, by contrasting itself with other communities. One of the ways of such a definition of Europe is to differentiate between "friends" and "foes", the definition of "European", "almost European", and "non-European" peoples. Yes, the "foe" is considered not as another but a stranger who embodies own negative traits and those characteristics that pose a significant threat to "friends". Therefore, exclusive identity implies the expulsion of others from Europe, thereby identifying "friends" (Moravcsik, 1993).

Given the inclusive and exclusive interpretations of the concept of Europe, it is worth considering possible variations on the concept of Europe in the future, those factors that will influence its change, the consequences for EU policy, and its future existence as a political entity. The main reason for the debate on the EU is its attitude to the enlargement of the EU's borders, the admission of new members, and the softening of visa policy with other countries. According to the original definition of Europe as a political project and conditional construct, the content of the concept of Europe will continue to be determined in the near future by the European Union, provided that its actual integrity and influence in world politics are preserved (Majone, 2005).

Instead, further discussions on the enlargement of the European Union, ethno-cultural conflicts in Europe, increased influence of nationalist movements, dissatisfaction with the political balance among EU countries on the part of both old and new members may threaten with the reformation of the Union, its collapse, or vice versa, strengthening centralization and unification.

\section{Results and discussion}

\subsection{Formation of the modern concept of Europe}

Unfortunately, the uniqueness and unprecedented nature of the European integration project do not make it possible to fully apply instruments of comparative analysis. However, the EU as a flagship of good governance practices provides the basis for the birth of new theories of the formation of a new concept of development and interaction of countries and the formation of a system of governance.

Thus, the process of transformation of the implemented legislation is not limited exclusively to its use in administrative practice in this Member State but may lead to adequate legal changes due to the ability to affect the lawmaking process at the European level.

Therefore, it is appropriate to consider the system of multi-level governance established in the EU through the prism of neoinstitutionalism of limited rational choice, in order to find out its potential impact on the formation of the institutional environment for decisionmaking and implementation of decisions within the EU.

The EU's multi-level governance system is based on several levels: supranational (European Commission, European Parliament, European Court of Justice, European Central Bank, Chamber of Auditors), interstate (European Council, EU Council), national (Member States), regional. At the same time, EU citizens who delegate their powers to the European Parliament and national parliaments remain somewhat out of the question. In the case of transfer of functions from the national level to the interstate or supranational, there is a concentration of functions in these institutions. When it comes to subsidiary devolution of authority from supranational, intergovernmental to the national or regional level, or from national to regional, we are dealing with decentralization (Hutton, 2004).

In a multi-level governance system, the principal may be collective (as in the case of Member States) or individual (EU institution). A collective and individual principal can create not only one agent but even several agents. As the practice of European integration shows, it is the creation of new institutions rather than the choice of existing agents.

Following the concept of trust management, supranational European institutions are increasingly becoming quasi-principals for Member State majority institutions. Moreover, the regulatory bodies of a Member State participating in the European System of Agencies are also evolving and taking on a new role of quasi-principal in relation to national institutions at the national level. All this suggests that the current state of bilateral relations between Member States and EU technocratic institutions, as well as between the Europeanised system of national agencies and the ministries that oversee their activities, casts doubt on the arsenal of tools of the agent-principal theory. Perhaps it is time to formulate new theoretical paradigms that would define these relations (Everson, 1995).

At the same time, delegation of state functions to autonomous institutions in virtually all European countries has created a twofold mechanism that, on the one hand, weakens democracy by reducing the competencies of public institutions and their level of support in society, 
and on the other, reduces the deficit of democratic legitimacy of EU institutions. The development of these processes may be related to the tendency to move away from intergovernmental management logic in the European Union in favour of management logic based on the autonomy of European technocratic institutions and the development of functional policy networks (Thatcher, Stone Sweet, 2002).

The principal-agent theory model quite clearly defines the essence of the state-administrative mechanisms in the relations between the main actors. However, further theoretical research would be more appropriate to concentrate on the issue of discontinuation arising from the two-step decision-making and implementation in the EU law system when, in the context of high political dynamics, the decisions made by the previous government have to be implemented by another government (Pollack, 2003).

Institutionalism as a methodological basis creates conditions for intensification of various studies of social systems, provides tracking of institutional quantitative and qualitative changes and transformations of different social institutions, analysis of institutional factors a set of fundamental historical prerequisites, political, economic, legal, social and spiritual (cultural) rules and norms that determine the framework conditions for the functioning and development of social systems as objects of public administration.

\section{Conclusions}

According to neoinstitutionalism, not only economic problems but also social, political, ethical, legal, and other problems are the basis of the analysis. While evolving, institutionalism has gained new features, its place has changed, its ideas have affected the views of many economists, and its importance is constantly growing.

Spreading the ideas of radical Eurosceptics can dramatically change the interpretation of the concept of Europe from its positive and progressive meaning to the negative, threatening, and outdated. An example would be the 2017 referendum on the withdrawal of the UK from the EU.

Such an example can be the 2017 referendum on the withdrawal of the UK from the EU. As noted by Sarah Hobolt, a researcher at the London School of Economics and Political Science, "While the EU may well be able to outrun Britain's exit - always a rebellious Member State - it is most worrisome that it can cause a domino effect with referendums in other countries" (Hobolt, 2016).

The notion of the modern concept of Europe can be seen as synonymous with political, economic, cultural unification, which leads to the degeneration of nations and the mixing of cultures.

In an inclusive aspect, the future of the European Union is to further involve all new regions, states, and territories in European practices, further integrate and enlarge the European Union. The so-called "Eurooptimists" or "Europhiles" positively perceive the development trends of the European Union and consider the European project a unique political-territorial entity, which has every opportunity for further expansion and increase of its influence.

The most influential scientific and political current in this context is Europeanism. Within Europeanism, it is recognized that the peoples of Europe have common values, a common history, and a common future. The politics, economy, culture of Europe must come from an understanding of the common identity of the European peoples. Integration into the $\mathrm{EU}$ is considered as a logical and appropriate step by all European countries, which should be promoted both by the Union itself and by non-member countries.

The leading theory of the inclusive aspect of interpreting the future development of the $\mathrm{EU}$ is federalism as one of the oldest ideas for the integration of the European space. At its core, federalism involves the creation of an EU state with a federal territorial system. Instead, in today's interpretation, federalism in Europe implies the integration but not the assimilation of all spheres of socio-political life. So, Belgian politician and researcher Guy Verhofstadt in the paper titled "The United States of Europe: Manifesto for a New Europe" (2005), based on growing public distrust of EU political institutions, proposes joint coordination of EU economies and centralized protection of the European social model (Verhofstadt, 2007).

A more moderate vision of the future of Europe is the theory of preserving stability and all the political and economic achievements and best practices of the European Union that it has in the first decade of the XXI century. The key ideas of the theory were developed by Stanley Hoffmann within the framework of the theory of intergovernmentalism, adopting and developing which Andrew Moravcsik formulated the theory of liberal intergovernmentalism, under which "the most influential in the foreign policy of the identity of important social groups, the nature of their interests, and their relative influence on the domestic policy" (Moravcsik, 1993). Following S. Hoffmann, he proposed to consider the actions of national governments at two levels: the national one, where direct interaction with the electorate takes place, and the European one, at which supranational organizations encourage governments to reach compromises and implement agreements. Being influential political ideas, federalism and intergovernmentalism, if further propagated and embodied in European policy, will lead to an even closer association of the concept of Europe with the European Union, since the localization of Europeanness in the EU will take place.

In addition, in an inclusive aspect, one can consider the modern concept of "A Europe of Regions", which 
includes the possibility of transition of European policy from the state and national to the regional level, which is implemented by public organizations and civil society movements. Regional governance will gradually dominate, in which case the existence of rigid or flexible borders of the EU does not play a significant role, on the contrary, the Union is not seen as a major political actor in Europe since all cooperation takes place between similar actors interested in the development of common policies. However, such a concept does not take into account the facts that, first of all, the implementation of the concept of "Europe of Regions" will be implemented by the EU institutions, which makes it politically dependent. Secondly, it is not profitable for EU elites to abandon national policies in favour of the regional policy, as they will lose their influence and authority both locally and in the international arena.

\section{References:}

Altvater, E., \& Mahnkopf, B. (2007). Konkurenz fur das Empire. Die Zukunft der Europaischen Union in der globalizierten Welt. Munster: Verlag Westfalisches Dampfboot.

Bretherton, C., \& Vogler, J. (2006). The European Union as a global actor. London; New York: Routledge.

Bretherton, C., \& Vogler, J. (2006). The European Union as a global actor. London; New York: Routledge.

Comp. S. Ross. (1973). The Economic Theory of Agency: The Principal's Problem. American Economic Review, vol. 63, no. 2.

Davis, N. (2006). Europe. History. Kiev: Publishing House by Solomiya Pavlichko "Fundamentals".

Everson, M. (1995). Independent Agencies: Hierarchy Beaters? European Law Journal, vol. 1, no. 2.

Verhofstadt, G. (2007). United States of Europe: Manifesto for a New Europe. Kyiv: Publishing house "K.I.S.".

Hobolt B. Sara. (2016). The Brexit vote: a divided nation, a divided continent. Journal of European Public Policy, pp. 1259-1277.

Hutton, W. (2004). The World We Live in: [trans. from English V. L. Inozemtseva]. Moscow: Ladomir.

Kurth, J. (2003). Western Civilization, Our Tradition. The intercollegiate review - Fall 2003/Spring 2004.

Lazor, O. (2010). Theoretical and methodological basis of the Institute of Public Self-Government. Retrieve from: http://www.nbuv.gov.ua/portal/Soc_Gum/Dtr_du/2010_2/files/DU210_32.pdf

Lekar, S., Martynyuk, O., Shumeiko, D., Lagodiienko, V., Nemchenko, V., \& Nikoliuk, O. (2019). The Use of Bayesian Networks in Public Administration of the Economy. International Journal of Engineering and Advanced Technology (IJEAT), 8(5), 1419-1421.

Majone, G. (2005). Dilemmas of European integration. The ambiguities and pitfalls of integration by stealth. Oxford New York: Oxford University Press.

Moravcsik, A. (1993). Preferences and Power in the European Community: A Liberal Intergovernmentalist Approach. II Journal of Common Market Studies, 31(4), 473-524.

Munchler, G. (2007). Europe as a Political Idea. II Journal. Retrieved from: http://www.ji.lviv.ua/n50texts/ muenkler.htm

Petroe, O. (2012). Institutional approach as a methodological basis for research and analysis of social systems in public administration. Retrieve from: http://nbuv.gov.ua/UJRN/znpnadu_2012_2_23

Pollack, M. A. (2003). The Engines of European Integration: Delegation, Agency, and Agenda Setting in the EU. Oxford: Oxford University Press.

Places (2018). The Global Open Data Index. Retrieved from: https://index.okfn.org/place/

Ruszkowski, J. (2008). Zastosowanie teorii PAT do analizy wielopoziomowego zarzdzania w UE. Studia Europejskie, 4. Retrieved from: http://www.ce.uw.edu.pl/pliki/pw/4-2008_Ruszkowski.pdf

Simon, G. (1992). The Means ofEconomic Thought. The theory of the firm. Retrieve from: http://economicus.ru/cgi-ise/ gallery/frame_rightn.pl?type=in\&links=./in/simon/works/simon_w1.txt\&img=works_small.gif\&name=simon Telo, M. (2006). Europe: a civilian power? European Union, global governance, world order. Basingstoke: Hants, New York: Palgrave Macmillan.

The Open Data Barometer (2016). Retrieved from: http://opendatabarometer.org/?_year=2016\&indicator=ODB Thatcher, M., \& Stone Sweet, A. (2002). Theory and Practice of Delegation to Non-Majoritarian Institutions. West European Politics, 25(1). 